\title{
Trolley Problem Decisions Follow the Laws of Inclusive Fitness
}

Jonathan Baker, Lyndsay Nelson, Kimberly Melby, Mark Remiker, Sarah Brandt, and April Bleske-Rechek University of Wisconsin-Eau Claire
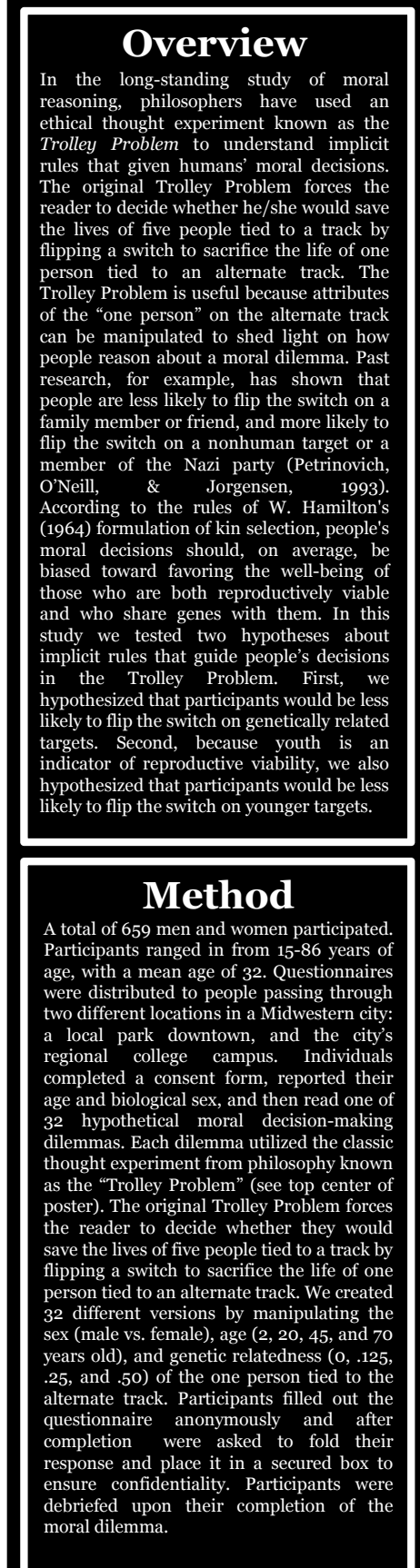
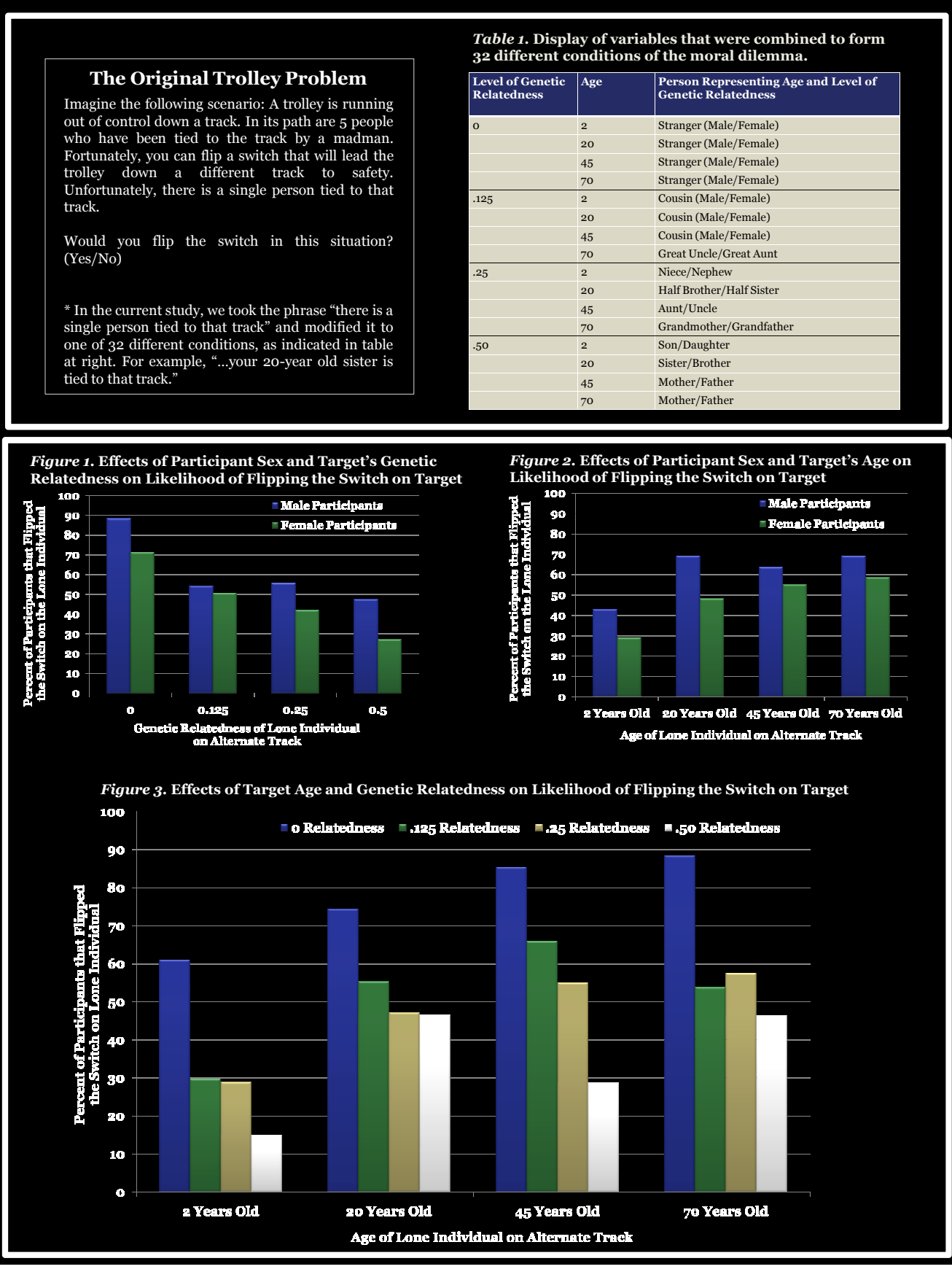
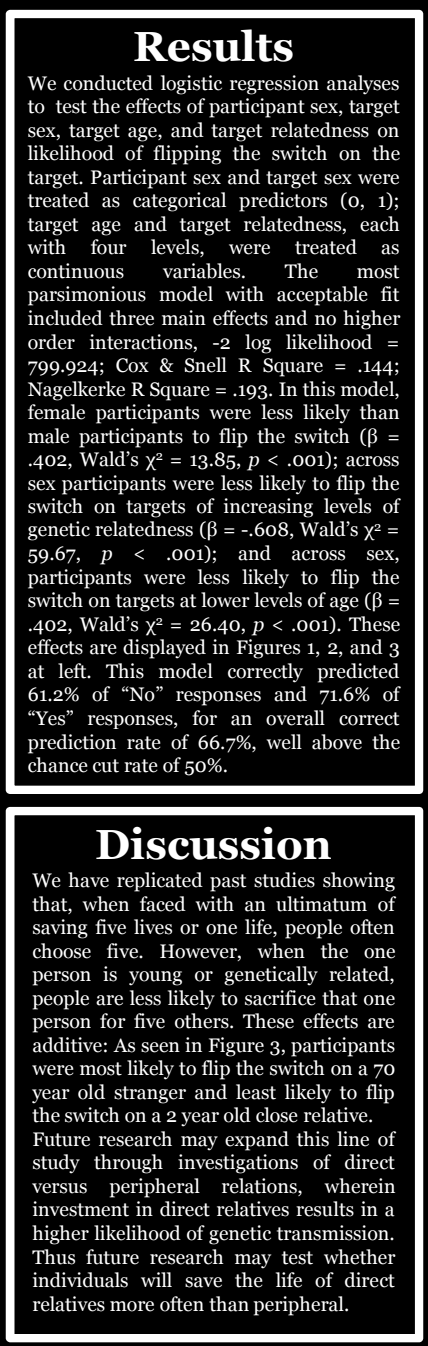

References

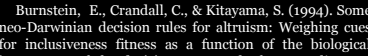

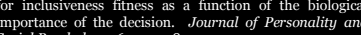

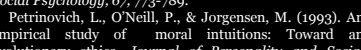

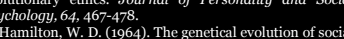

